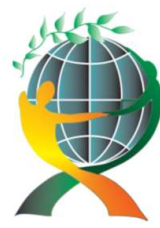

\author{
(online) $=$ ISSN $2285-3642$ \\ ISSN-L = $2285-3642$ \\ Journal of Economic Development, Environment and People \\ Volume 8, Issue 1, 2019
}

URL: http://jedep.spiruharet.ro

e-mail: office jedep@spiruharet.ro

\title{
Knowledge Sharing among Employees in Organizations
}

\author{
Haradhan Kumar MOHAJAN \\ Assistant Professor, Premier University, Chittagong, Bangladesh \\ Email: haradhan1971@gmail.com
}

Mobile: +8801716397232

\begin{abstract}
Knowledge is considered as the basis for developing sustained long-term competitive advantage for every organization. In the $21^{\text {st }}$ century every organization becomes knowledge based for the sustainable development. Knowledge sharing is an important instrument that turns individual knowledge into group organizational knowledge. It is one of the main knowledge processes in a present dynamic and competitive era for the development of organizations. The knowledge sharing practice plays a remarkable role in the development and innovation in many areas of organizations. In this paper an attempt has been taken to discuss techniques, barriers and benefits of knowledge sharing in organizations.
\end{abstract}

Keywords: Knowledge sharing, organization, globalization

JEL Codes: D2, L2

How to cite: Mohajan, H. K. (2019). Knowledge Sharing among Employees in Organizations. Journal of Economic Development, Environment and People, 8(1), 52-61. doi: http://dx.doi.org/10.26458/jedep.v8i1.612

\section{Introduction}

In the $21^{\text {st }}$ century, due to globalization, increasing competition, technological advancements, and the rapid aging of the population; organizations are facing the need to change their policies and strategies (Shah \& Shah, 2010; Shannak et al., 2012). Hence, we need to think on new knowledge management (KM) practices for the sustainable development of organizations. Knowledge sharing (KS) in an organization is necessary and one of the best way to develop KM practices in the organizations (Beijerse, 1999).

Knowledge is a powerful source of organizations. The importance of knowledge for the development of organizations globally took attention to the researchers in the late 1990s. The World Bank (1998) explained that knowledge, specifically the way a society produced, processed, and integrated knowledge into their lives, was a crucial factor for the organizational development. At present, knowledge is considered as an essential issue of production in an organization as like land, labor, and capital. Knowledge is a fluid mix of experience, contextual information and expert insight that provides a framework for evaluating and incorporating new experiences and information (Davenport \& Prusak, 1997). In organizations, knowledge is divided into two types: explicit and tacit knowledge (Nonaka, 1991). Tacit knowledge is the hands-on skills, best practices, special know-how, heuristic, intuitions, and so on. It is personal in origin, context and job specific and difficult to formalize and codify, difficult to capture, communicate and share, and poorly documented but highly operational in the minds of the possessor (Polanyi, 1973; Serban \& Luan, 2003). 


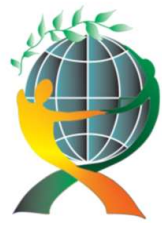

\author{
(online) $=$ ISSN $2285-3642$ \\ ISSN-L = $2285-3642$ \\ Journal of Economic Development, Environment and People \\ Volume 8, Issue 1, 2019 \\ URL: http://jedep.spiruharet.ro \\ e-mail: office jedep@spiruharet.ro
}

Explicit knowledge is easily codified, storable, transferable, and easily expressed and shared. Sources of it are manuals, policies and procedures, and databases and reports (Serban \& Luan, 2003).

All the activities related to the transmission and distribution of knowledge among individuals, groups or organizations are considered as KS (Lee, 2001; Ling et al., 2009). KS is defined as the activity through which knowledge, such as information, skills, plans, innovation, ideas, goals, insights, or expertise is exchanged among people, peers, community, friends, families, or organizations (Bukowitz \& Williams, 1999). It refers to the exchange of knowledge between at least two parties in a reciprocal process allowing reshape and sense making of the knowledge in the new context (Willem, 2003).

$\mathrm{KS}$ is the movement of knowledge among individuals in organizations to help others and to collaborate with others for solving problems, develop new ideas, or implement policies or procedures (Wang \& Noe, 2010). Therefore, it is the process by which the knowledge possessed by individuals is converted into a form that can be understood and used by other individuals, and which is beneficial for all. In this process people can exchange explicit and tacit knowledge with each other and can create new knowledge (van den Brink, 2003). It is an activity of sharing experiences and individual information in an organization. It takes place as social interaction that involves the exchange of employee knowledge, experiences, and skills throughout an organization by some form of communication (Teeni, 2006; Lin, 2007).

KS provides huge impacts to the creation of learning organizational culture, knowledge, and innovation (Casimir, 2012). Therefore, KS identifies existing and accessible knowledge in order to transfer and tally this knowledge to solve specific tasks better, faster and cheaper than through other solving methods (Christensen, 2007). It depends on individual factors, such as, beliefs, experience, motivation, expectations, perceptions, attitudes, values, and mind-setting towards KS (Lin, 2007; Volady, 2013). On the other hand, organizational KS depends on feedback and valuable contributions and participation from colleagues, and the level of collaboration in and across the business units. The managerial KS covers the responsibility of providing sufficient training, valuing contributions, giving affirmative feedback, participation and organizational guidelines for using social media tools (Wahlroos, 2010).

A successful KM depends on efficient and fruitful KS among employees in organizations (Wang \& Noe, 2010). For the sustainable development and long-term survival of any organization, effective and efficient KS is essential (Gaal et al., 2008). Now, KS in organizations is increasing day by day and is considering as an essential element for successful and effective development cooperation (Kim \& Tcha, 2012).

\title{
2. Literature Review
}

Guodong Ni, Qingbin Cui, Linhua Sang, Wenshun Wang, and Hongyi Huang have examined the mechanism to improve knowledge sharing performance (KSP) with a specific focus on knowledge sharing culture (KSC) and project team interaction (PTI) in 78 Chinese engineering management organizations. Their research has shown that there is a significant positive correlation among KSC, KSP, and PTI (Ni et al., 2016). Bader Yousef Obeidat, Ayman Bahjat Abdallah, Noor Osama Aqqad, Abdel Hakeem Oqlah M. Akhoershiedah, and Mahmoud Maqableh have studied the various effects that exist among intellectual capital, knowledge sharing, and organizational performance on 356 employees working in manufacturing companies in Jordan. Their result has revealed that intellectual capital had a positive effect on organizational performance and KS (Obeidat et al., 2017). A. I. Susanty, M. Salwa, A. Chandradini, F. W. Evanisa and N. Iriani indicate how the enabling factors influence KS in 267 employees from three different companies in Indonesia (Susanty et al., 2016). Sheng-Wei Lin and Louis Yi-Shih Lo have found that the rewards and inspirations can enhance the KS among employees (Lin \& Lo, 2015). According to Hung-Wen 


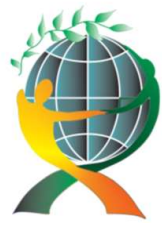

\author{
(online) $=$ ISSN $2285-3642$ \\ ISSN-L = $2285-3642$ \\ Journal of Economic Development, Environment and People \\ Volume 8, Issue 1, 2019 \\ URL: http://jedep.spiruharet.ro \\ e-mail: office jedep@spiruharet.ro
}

Lee and Ching-Fang Yu (2011), KS enables individuals to share knowledge to others, which benefits the organization. Minu Ipe (2003) point out that KS in organizations is a complex process. The authors also indicate that there are four main factors that influence KS process in an organization as: 1) nature of knowledge, 2) motivation to share, 3) opportunities to share, and 4) culture of work environment.

A study conducted by Mccall et al. (2008) reveals that, the four factors that influence KS are: i) individual factor, which is closely related to one's behavior to KS to others, ii) relational factor, which refers to individual relationship in a group, iii) informational factor, that is a complex type of knowledge, and iv) organizational factor, which is related to emotional bond between individual and organization. Karl-Erik Sveiby and Roland Simons have identified fifty factors mentioned in the literature on culture and employee attitude that influence KS, trust, and collaboration. They have highlighted attitudes among employees and teams, the KS behavior of supervisors, and organizational culture (Sveiby \& Simons, 2002). Hsiu-Fen Lin (2007) has found bias on gender, age, organizational tenure, job position and ethnicity. His opinion is that these will be critical in KS. He has provided a significant correlation between instrumental ties and KS among women as compared to men.

Sylvie Geisendorf and Felicitas Pietrulla have tried to give a revised definition of the circular economy after having analyzed and compared the most prominent related concepts (Geisendorf \& Pietrulla, 2017). Patrizia Ghisellini, Catia Cialani, and Sergio Ulgiati in a review on circular economy have provided that circular economy increases the efficiency of resource use, with special focus on urban and industrial waste, to achieve a better balance and harmony between economy, environment and society. They have stressed on ecological and environmental economics and industrial ecology (Ghisellini et al., 2016).

\title{
3. Methodology of the Study
}

In this article we have used the secondary data. We have taken helps from websites, books, previous published articles, theses, conference papers, case studies and various research reports for the preparation of this article. In the study, we have tried to discuss the various sides of KS technologies within organizations.

\section{Objective of the Study}

The objectives of this study are to represent KS strategies in organizations. We have also taken an attempt to discuss the following points:

- the aspects of KS,

- the importance of KS, and

- the improvement of the KS practices in organizations.

\section{Types of KS in Organizations}

There are two types of KS activities: i) intra-firms, and ii) inter-firms KS (Lee et al., 2016). Intra-firm KS activity is performed within the same organization through formal and informal meetings, dialogs and social networks. As a result knowledge of the organization can be updated for future use (Vij \& Faroop, 2014). Inter-firm KS activity is performed in different organizations, which allows firms to create value, share R\&D, attain leadership, and access new efficient markets (Anand \& Khanna, 2000; Lee et al., 2016).

KS is divided into three generations as follows (Bellefroid, 2012): 


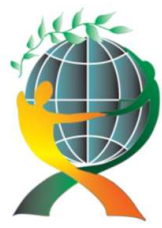

\author{
(online) $=$ ISSN $2285-3642$ \\ ISSN-L = 2285 - 3642 \\ Journal of Economic Development, Environment and People \\ Volume 8, Issue 1, 2019 \\ URL: http://jedep.spiruharet.ro \\ e-mail: office jedep@spiruharet.ro
}

The first generation: It is the traditional way of KS and stands on the basis concept of codification and storage which is supported by information technologies (Hansen et al., 1999). Codification is used as a starting point, were new employees can find out what others know and what knowledge is available.

The second generation: It focuses on the social component and personalization, so that people cooperate and communicate. Mentoring, coaching or face-to-face meetings are opportunities to share knowledge (Hansen et al., 1999). Personalization is the application of the available knowledge in the organization.

The third generation: It is social networks that provide a new way to get in touch with experts and to search for knowledge outside the organization. It deals with the function of knowledge ecology, chaos and the sensing of opportunities (Scharmer, 2001).

\title{
6. Process of KS in Organizations
}

KS can be represented as a two-dimensional process with members of staff sharing and exchanging their tacit and explicit knowledge. Regular KS creates new knowledge through the process of knowledge donation and collection (Hooff \& Weenen, 2004).

Donation of knowledge: It represents the willingness and eagerness of individuals in organizations to give and share their knowledge with others through listening, talking to others to develop their self-knowledge and solve problems more quickly (Cumming, 2004; Lin, 2007)

Collection of knowledge: It indicates the receiver of knowledge who must consult colleagues through observation, listening or practicing from internal and external sources, and also to encourage them to share their intellectual capital (Hooff \& Weenen, 2004; Lin, 2007).

Donation and collection processes increase trust and mutual respect as well as facilitate the flow of individuals' knowledge assets to capitalize for performance development (Kamasak \& Bulutlar, 2010).

Peter Holdt Christensen identifies four forms of knowledge which are parts of the KS process: i) professional knowledge, ii) coordinating knowledge, iii) object-based knowledge, and iv) know-who. Professional knowledge is created and shared within communities of practices (CoPs) either inside or across organizational barriers. It is originated from a person's formal education in combination with his experience in performing his job. Coordination knowledge makes each employee knowledgeable of how and when he is supposed to apply knowledge in the organization. It is embedded in rules, standards and routines for how jobs are supposed to be performed. Object-based knowledge is about an object that passes along the organization's production line. The combination of professional knowledge and coordinating knowledge is applied to a certain object such as, a patient, a machine or a customer. Know-who is knowledge about who knows what, or who is supposed to perform activities that influence organizational activities of others. It enables the identification of who might be able to help solve specific problems. These four forms emphasize that knowledge is being shared as a means for efficiently transforming an input to an organizational output (Christensen, 2007).

\section{KS in Circular Economy}

A circular economy (CE) is an economic system that tries to minimize waste and makes the most of resources which are ignored by the traditional linear economy. It aims to develop growth, and focuses on positive society-wide benefits. It promotes 3R (reduce, reuse and recycle) policies (Geissdoerfer et al., 2017). It encourages gradually decoupling economic activity from the consumption of finite resources, and designing waste out of the system. It helps to reduce pollution, use fewer natural resources, tackle climate 


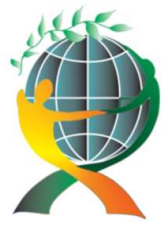

\author{
(online) $=$ ISSN $2285-3642$ \\ ISSN-L = $2285-3642$ \\ Journal of Economic Development, Environment and People \\ Volume 8, Issue 1, 2019 \\ URL: http://jedep.spiruharet.ro \\ e-mail: office jedep@spiruharet.ro
}

change, use waste as a resource, and reduce the environmental impacts of global production and consumption. It is based on three principles:

- design out waste and pollution,

- keep products and materials in use,

- regenerate natural systems,

$\mathrm{KS}$ is very important in order to develop companies that respect the principles of CE. Organizations can save money and make money by applying KS in CE. Because, in CE everything is reused, remanufactured, recycled back into a raw material. It enhances natural capital, optimizes resource yields, and minimizes system risks by managing finite stocks and renewable flows (de Man \& Friege, 2016).

KS in CE can increase resource benefits by conserving materials embodied in high-value products, or returning wastes to the economy as high-quality secondary raw materials. As a result, demand for primary raw materials will be reduced and organizations will gain more profits (Meyer, 2011). KS in CE can develop environmental achievements for economic output and social well-being. Waste recycling reduces greenhouse gas emissions. Keeping materials in the loop would also enhance ecosystem resilience and the environmental impacts of mining raw materials (European Environmental Agency, EEA, 2016). KS in CE can find economic benefits. A CE could provide massive cost savings for various industries by recycling the wastes. KS in CE can achieve social benefits. Social innovation associated with sharing, eco-design, reuse and recycling can create sustainable consumer behavior and improve human health. It also creates job opportunities (Wysokinska, 2016).

\title{
8. Building KS in Organizations
}

There are five factors that influence the extent to which KS takes place as follows (Gupta \& Govindarajan, 2000):

- perceived value of the source's knowledge,

- willingness of the source to share knowledge,

- existence and richness of transmission channels,

- willingness of receiver to acquire knowledge from the source, and

- absorptive capacity of the receiver.

There are four mechanisms in KS within an organization: i) knowledge contribution to an organizational database, ii) KS in a formal interaction or a team or a division, iii) KS in an informal interaction between individuals, and iv) voluntarily KS in a community related to interesting topics (Kharabsheh, 2007).

The potential motivations behind KS behavior are as follows (Davenport \& Prusak, 1997):

Altruism: It refers to behavior that costs an individual, and benefits the other individual. People contribute something to other people without thinking of any returns when showing altruistic behavior (Chattopadhyay, 1999).

Reciprocity: It indicates either a positive or negative response for the actions which one should treat others as one would like others to treat one.

Reputation: It refers to a degree of recognition and is increased by information sharing among other users. People who share more knowledge receive a higher reputation.

KS is used in two ways: exploitation and exploration. Exploitation is the processes where existing knowledge is captured, transferred, and deployed. Exploration is the processes where knowledge is shared, synthesized, and new knowledge is created (McElroy, 2003). 


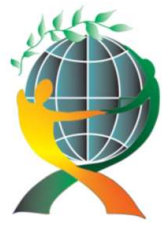

\author{
(online) $=$ ISSN $2285-3642$ \\ ISSN-L = $2285-3642$ \\ Journal of Economic Development, Environment and People \\ Volume 8, Issue 1, 2019 \\ URL: http://jedep.spiruharet.ro \\ e-mail: office jedep@spiruharet.ro
}

\title{
9. Barriers to $\mathrm{KS}$ in Organizations
}

Barriers are the hinder of flow of knowledge among employees in organizations. KS practices have not accomplished properly in many organizations due to possible KS barriers. Lack of trust is a significant barrier for KS in organizations. The influence of the organizational culture, lack of proper leadership, and lack of appropriate rewards in the organization are barriers of KS (Zawawi et al., 2011). Lack of communication, inequalities in status, lack of leadership and managerial direction, deficiency of sharing resources in organization, lack of formal and informal mechanisms and spaces to improve sharing activities, missing of sharing initiatives into the organization, deficiency of sharing resources, lack of proper space of KS, unwilling of sharing knowledge of highly skilled and experienced staff, and lack or an exiguity of network connections are barriers to organizational KS (Riege, 2005).

Shortage of skilled personnel, finance, and information and communication technology are also barriers to KS in organizations. Most cases employees in organizations are reluctant to share knowledge among themselves because of lack of time and effort to KS, lack of motivation and credibility, fear of one's KS may lessen job security, poor evaluations by the receiving unit, differences in education levels, and lack of social network (Chiu et al., 2006; Dyer \& Hatch, 2006).

\section{Benefit of KS in Organizations}

The KS among employees creates many benefits for an organization and some of them are; allowing the organization to build on previous knowledge and experiences, responding to problems more quickly, developing new ideas, fostering innovation, understanding customer needs, and building competencies (Cyr \& Choo, 2010). KS facilitates the spread of knowledge as organizational collective knowledge, and helps the firm use available resources in an efficient and effective manner (Argote $\&$ Ingram, 2000). It covers knowledge identification, and access to be transferred and applied to solve problems, so that the organizational tasks can be done effectively and less costly (Shaari et al., 2014).

KS helps to the proper utilization of existing knowledge and is also to create new knowledge (Nonaka, 1994). It improves job performance, increases intellectual capital, changes individual competitiveness, changes organizational competitiveness, and reduces operational costs of the organizations (Jackson et al., 2006). Proper implementation of KS can lead to effective innovation, manufacturing processes, organizational designs, and quality products. Hence, effective KS practices can enhance the development of new products, as well as new quality processes (Cummings, 2003). By KS the employees of an organization connected with external sources, and can gain new information, experience and ideas that might not be found inside the organization (Wasko \& Faraj, 2005). KS is important for creating a new knowledge in order to achieve competitive advantage which increase turnover of staff (Gurteen, 1999).

\section{Conclusion}

In this study we have tried to describe KS activities in the organizations. The authorities of organizations must be sincere for sharing knowledge elaborately to develop the organizations. We observed that during KS some barriers may occur to restrict the effective activities in organizations. These barriers must be overcome using the positive mentality that KS increases the effectiveness and quality of work to improve of their overall performance for the benefit of their organizations. We hope, the top managements of organizations must facilitate the KS system, and encourage their employees to share knowledge among the organizations. 


\author{
(online) $=$ ISSN $2285-3642$ \\ ISSN-L = $2285-3642$ \\ Journal of Economic Development, Environment and People \\ Volume 8, Issue 1, 2019 \\ URL: http://jedep.spiruharet.ro \\ e-mail: office jedep@spiruharet.ro
}

\title{
12. References
}

[1] Anand, B. N., \& Khanna, T. (2000). Do Firms Learn to Create Value? The Case of Alliances. Strategic Management Journal, 21(3), 293-315.

[2] Argote, L., \& Ingram, P. (2000). Knowledge Transfer A Basis for Competitive Advantage in Firms. Organizational Behavior and Human Decision Processes, 82(1), 150-169.

[3] Beijerse, R. P. (1999). Questions in Knowledge Management: Defining and Conceptualizing a Phenomenon. Journal of Knowledge Management, 3(2), 94-110.

[4] Bellefroid, B. (2012). The New Way of Knowledge Sharing a Thesis Research about the Effects of NWOW on Knowledge Sharing. http://dspace.library.uu.nl/bitstream/handle/1874/268187/Thesis_BartBellefroid_v1.01_final_screen.pdf?seque $\underline{\text { nce }=1}$

[5] Bukowitz, W. R., \& Williams, R. L. (1999). The Knowledge Management Fieldbook. Financial Times: Prentice Hall.

[6] Casimir, G. (2012). Knowledge Sharing: Influences of Trust, Commitment and Cost. Journal of Knowledge Management, 16(5), 740-753.

[7] Chattopadhyay, P. (1999). Beyond Direct and Symmetrical Effects: The Influence of Demographic Dissimilarity on Organisational Citizenship Behavior. Academy of Management Journal, 42(3), 273-287.

[8] Chiu, C.-M., Hsu, M.-H., \& Wang, E. T. G. (2006). Understanding Knowledge Sharing in Virtual Communities: An Integration of Social Capital and Social Cognitive Theories. Decision Support Systems, 42(3), 1872-1888.

[9] Christensen, P. H. (2007). Knowledge Sharing: Moving Away from the Obsession with Best Practices. Journal of Knowledge Management, 11(1), 36-47.

[10] Cummings, J. (2003). Knowledge Sharing: A Review of the Literature. Operation Evaluation Department Working Paper, World Bank.

[11] Cummings, J. (2004). Work Groups Structural Diversity and Knowledge Sharing in a Global Organization. Management Science, 50(3), 352-364.

[12] Cyr, S., \& Choo, C. W. (2010). The Individual and Social Dynamics of Knowledge Sharing: An Exploratory Study. Journal of Documentation, 66(6), 824-846.

[13] Davenport, T. H., \& Prusak, L. (1997). Working Knowledge: How Organizations Manage What They Know. Harvard Business School Press, Boston, MA, USA.

[14] de Man, R., \& Friege, H. (2016). Circular Economy: European Policy on Shaky Ground. Waste Management \& Research, 34(2), 93-95.

[15] Dyer, J., \& Hatch, N. (2006). Relation-Specific Capabilities and Barriers to Knowledge Transfers: Creating Advantage through Network Relationships. Strategic Management Journal, 27(8), 701-719.

[16] EEA (2016). Report / No. 2/ 2016: Circular Economy in Europe-Developing the Knowledge Base. Luxembourg: European Environmental Agency.

[17] Gaal, Z., Szabo, L., Kovacs, Z., Obermayer-Kovacs, N., \& Csepregi, A. (2008). Knowledge Management Profile, Maturity Model. In Proceedings of $9^{\text {th }}$ European Conference on Knowledge Management (ECKM 2008), pp. 209216, Southampton, UK. 


\author{
(online) $=$ ISSN $2285-3642$ \\ ISSN-L = $2285-3642$ \\ Journal of Economic Development, Environment and People \\ Volume 8, Issue 1, 2019 \\ URL: http://jedep.spiruharet.ro \\ e-mail: office jedep@spiruharet.ro
}

[18] Geisendorf, S., \& Pietrulla, F. (2018). The Circular Economy and Circular Economic Concepts-A Literature Analysis and Redefinition. Thunderbird International Business Review, 60, 771-782.

[19] Geissdoerfer, M., Savaget, P., Bocken, N. M. P., \& Hultink, E. J. (2017). The Circular Economy: A New Sustainability Paradigm? Journal of Cleaner Production, 143(1), 757-768.

[20] Ghisellini, P., Cialani, C., \& Ulgiati, U. (2016). A Review on Circular Economy: The Expected Transition to a Balanced Interplay of Environmental and Economic Systems. Journal of Cleaner Production, 114, 11-32.

[21] Gupta, A. K., \& Govindarajan, V. (2000). Knowledge Management's Social Dimension: Lessons from Nucor Steel. Sloan Management Review, 42(1), 71-80.

[22] Gurteen, D. (1999). Creating a Knowledge Sharing Culture. Knowledge Management Magazine, 2(5), Provide Sedge [Online] Available: http://www.providersedge.com/docs/km_articles/Creating_a_KSharing_Culture_Gurteen.pdf

[23] Hansen, M. T., Nohria, N., \& Tierney, T. (1999). What is Your Strategy for Managing Knowledge? Harvard Business Review, 77(2), 106-116.

[24] Hooff, V., \& Weenen, F. (2004). Committed to Share: Commitment and CMC Use as Antecedents of Knowledge Sharing. Knowledge and Process Management, 11(1), 13-24.

[25] Ipe, M. (2003). Knowledge Sharing in Organizations: A Conceptual Framework. Journal of SAGE, 2(4), 337-359.

[26] Jackson, S. E., Chuang, C., Harden, E. E., Jiang, Y., \& Joseph, J. M. (2006). Toward Developing Human Resources Management Systems for Knowledge-Intensive Teamwork. Research in Personnel and Human Resources Management, 25(6), 27-70.

[27] Kamasak, R., \& Bulutlar, S. (2010). Influence of Knowledge Sharing on Innovation. European Business Review, 22(3), 306-317.

[28] Kharabsheh, R. (2007). Model of Antecedents of Knowledge Sharing. Electronic Journal of Knowledge Management, 5(4), 419-426.

[29] Kim, Y., \& Tcha, M. (2012). Introduction to the Knowledge Sharing Program (KSP) of Korea. Tracing the Impacts of Korea's Engagements around the World, Korea Economic Institute.

[30] Lee, H. W., \& Yu, C. F. (2011). Effect of Organizational Relationship Style on the Level of Knowledge Sharing. International Journal of Manpower, 32(5/6), 677-686.

[31] Lee, J. N. (2001). The Impact of Knowledge Sharing, Organizational Capability and Partnership Quality on IS Outsourcing Success. Information and Management, 38(5), 5323-5335.

[32] Lee, W. J., Jun, J., \& Lee, T. (2016). Sharing Behavior and its Relationship with Core Competencies of a Company: A Grounded Theory Approach. Indian Journal of Science and Technology, 9(5), 1-9.

[33] Lin, H. F. (2007). Knowledge Sharing and Firm Innovation Capability: An Empirical Study. International Journal of Manpower, 28(3/4), 315-332.

[34] Lin, S-W., \& Lo, L. Y-S. (2015). Mechanisms to Motivate Knowledge Sharing: Integrating the Reward Systems and Social Network Perspectives. Journal of Knowledge Management, 19(2), 212-235.

[35] Ling, T. N., San, L. Y., \& Hock, N. T. (2009). Trust: Facilitator of Knowledge-Sharing Culture. Communications of the IBIMA, 7(15), 137-142. 


\author{
(online) $=$ ISSN $2285-3642$ \\ ISSN-L = $2285-3642$ \\ Journal of Economic Development, Environment and People \\ Volume 8, Issue 1, 2019 \\ URL: http://jedep.spiruharet.ro \\ e-mail: office jedep@spiruharet.ro
}

[36] Mathew, V. (2010). Service Delivery through Knowledge Management in Higher Education. Journal of Knowledge Management Practice, 11(3), 1-14.

[37] Mccall, H., Arnold, V., \& Sutton, S. G. (2008). Use of Knowledge Management Systems and the Impact on the Acquisition of Explicit Knowledge. Journal of Information Systems, 22(2), 77-101.

[38] McElroy, M. W. (2003). The New Knowledge Management; Complexity, Learning, and Sustainable Innovation. Butterworth-Heinemann, New York, NY.

[39] Meyer, B. (2011). Macroeconomic Modelling of Sustainable Development and the Links between the Economy and the Environment. ENV.F.1/ETU/2010/0033, Final Report. Gesellschaft für Wirtschaftliche Strukturforschung mbH.

[40] Ni, G., Cui, Q., Sang, L., Wang, W., \& Huang, H. (2016). Knowledge Sharing Culture, Project Team Interaction, and Knowledge Sharing Performance among Project Members. Proceedings of the Engineering Project Organization Conference (EPOC), Cle Elum, Washington, USA, June 28-30, 2016.

[41] Nonaka, I. (1991). The Knowledge-Creating Company. Harvard Business Review, 69(6), 96-104.

[42] Nonaka, I. (1994). A Dynamic Theory of Organizational Knowledge Creation. Organization Science, 5(1), 14-37.

[43] Obeidat, B. Y., Abdallah, A. B., Aqqad, N. O., Akhoershiedah, A. H. O. M., \& Maqableh, M. (2017). The Effect of Intellectual Capital on Organizational Performance: The Mediating Role of Knowledge Sharing. Communications and Network, 9, 1-27.

[44] Polanyi, M. (1973). Personal Knowledge. London, UK: Routledge \& Kegan Paul.

[45] Riege, A. (2005). Three-Dozen Knowledge-Sharing Barriers Managers Must Consider. Journal of Knowledge Management, 9(3), 18-35.

[46] Scharmer, C. O. (2001). Self-Transcending Knowledge: Sensing and Organizing Around Emerging Opportunities. Journal of Knowledge Management, 5(2), 137-151.

[47] Serban, A. M., \& Luan, J. (2003). Overview of Knowledge Management. New Directions for Institutional Research No. 113, Wiley Periodicals, Inc.

[48] Shaari, R., Rahman, S., \& Rajab A. (2014). Self-Efficacy as a Determined Factor for Knowledge Sharing Awareness. International Journal of Trade, Economics and Finance, 5(1), 39-42.

[49] Shah, N., \& Shah, S. (2010). Relationships between Employee Readiness for Organizational Change, Supervisor and Peer Relations and Demography. Journal of Enterprise Information Management, 23(5), 640-652.

[50] Shannak, R., Masa'deh, R., Al-Zu’bi, Z., Obeidat, B., Alshurideh, M., \& Altamony, H. (2012), A Theoretical Perspective on the Relationship between Knowledge Management Systems, Customer Knowledge Management, and Firm Competitive Advantage. European Journal of Social Sciences, 32(4), 520-532.

[51] Susanty, A. I., Salwa, M., Chandradini, A., Evanisa, F. W., \& Iriani, N. (2016). Knowledge Sharing and Implementation of its Enabling Factors: A Case Study of Three Types of Company in Indonesia. Pertanika Journal of Social Sciences \& Humanities, 24(S), 239-254.

[52] Sveiby, K., \& Simons, R. (2002). Collaborative Climate and Effectiveness of Knowledge Work: An Empirical Study. Journal of Knowledge Management, 6(5), 420-433.

[53] Teeni, D. (2006). Organizational Communication. In D. G. Schwartz (Ed.), Encyclopedia of Knowledge Management, pp. 734-740, USA: Idea Group Reference. 


\author{
(online) $=$ ISSN $2285-3642$ \\ ISSN-L = $2285-3642$ \\ Journal of Economic Development, Environment and People \\ Volume 8, Issue 1, 2019 \\ URL: http://jedep.spiruharet.ro \\ e-mail: office jedep@spiruharet.ro
}

[54] van den Brink, P. (2003). Social, Individual and Technological Conditions that Enable Knowledge Sharing. PhD Thesis, Universities van Amsterdam.

[55] Vij, S., \& Faroop, R. (2014). Knowledge Sharing Orientation and its Relationship with Business Performance: A Structural Equation Modeling Approach. IUP Journal of Knowledge Management, 12(3), 17-41.

[56] Volady, L. (2013). An Investigation of Factors Influencing Knowledge Sharing among Undergraduate Teacher Education Students. Adelaide, South Australia: wordpress.com. http://volady0002.wordpress.com/knowledgesharing-among-undegraduate-students/

[57] Wang, S., \& Noe, R. A. (2010). Knowledge Sharing: A Review and Directions for Future Research. Human Resource Management Review, 20(2), 115-131.

[58] Wasko, M. M., \& Faraj, S. (2005). Why Should I Share? Examining Social Capital and Knowledge Contribution in Electronic Networks of Practice. MIS Quarterly, 29(1), 35-57.

[59] Willem, A. (2003). The Role of Organization Specific Integration Mechanisms in Inter-Unit Knowledge Sharing. PhD Dissertation at Vlerick Leuven Gent Management School, Ghent University, Belgium.

[60] World Bank (1998). World Development Report 1998-99. Washington DC: World Bank.

[61] Wysokinska, Z. (2016). The "New" Environmental Policy of the European Union: A Path to Development of a Circular Economy and Mitigation of the Negative Effects of Climate Change. Comparative Economic Research, 19(2), 57-73.

[62] Zawawi, A. A., Zakaria, Z., Kamarunzaman, N. Z., Noordin, N., Sawal, M. Z. H. M., Junos, N. M., \& Najid, N. S. A. (2011). The Study of Barrier Factors in Knowledge Sharing: A Case Study in Public University. Management Science and Engineering, 5(1), 59-70. 